\title{
Resistance status and physiological activity test of Spenochlea zeylanica and Ludwigia octovalvis in paddy field to 2,4-D and metsulfuron-methyl herbicides
}

\author{
RIZKY RAHMADI", NANIK SRIYANI, YUSNITA, HIDAYAT PUJISISWANTO, DWI HAPSORO \\ Department of Agronomy and Horticulture, Faculty of Agriculture, Universitas Lampung. Jl. Prof. Dr. Ir. Sumantri Brojonegoro No. 1, Bandar Lampung \\ 35141, Lampung, Indonesia. Tel.: +62-721-704946, Fax.: +62-721-770347, ”email: rizkyrahmadi.170197@gmail.com
}

Manuscript received: 29 December 2020. Revision accepted: 25 April 2021.

\begin{abstract}
Rahmadi R, Sriyani N, Yusnita, Pujisiswanto H, Hapsoro D. 2021. Resistance status and physiological activity test of Spenochlea zeylanica and Ludwigia octovalvis in paddy field to 2,4-D and metsulfuron-methyl herbicides. Biodiversitas 22: $2829-2838$. Spenochlea zeylanica and Ludwigia octovalvis are dominant in Trimurjo paddy fields in Central Lampung Regency, Lampung, Indonesia and difficult to control with 2,4-Dichlorophenoxyacetic acid (2,4-D) and metsulfuron-methyl herbicides that had been used for more than 12 years. This study aims to determine the resistance status of S. zeylanica and L. octovalvis and physiological activity in resistance and susceptible of both weeds species exposed to 2,4-D and metsulfuron-methyl herbicides. The study was conducted from August to December 2019 in the Greenhouse Botanical Garden of Sumatra Institute of Technology. The study used a split-plot design, the origin of weed species as the main plot and herbicide dose as the subplot. S. zeylanica exposed has low-level resistance to 2,4-D and metsulfuron-methyl herbicides with resistance Index (RI) of 2.19 and 2.87, respectively. L. octovalvis exposed was still classified as susceptible to 2,4-D and metsulfuron-methyl herbicides with RI of 1.00 and 1.59, respectively. The physiological activities (carbon assimilation, stomatal conductance, and transpiration rate) of S. zeylanica resistant to 2,4-D and metsulfuron-methyl herbicides is higher than $S$. zeylanica susceptible 2,4-D and metsulfuron-methyl herbicides.
\end{abstract}

Keywords: 2,4-D, herbicides, metsulfuron-methyl, physiological, resistance, weeds

\section{INTRODUCTION}

The presence of weeds in paddy field has adverse impact on rice production. It has been reported that weeds might cause up to $76 \%$ of rice production (Sureshkumar et al. 2016). Weed management in paddy field is often by chemical method (herbicide) because more effective and efficient in terms of time and cost compared to other weed management (Abouziena and Haggag 2016; Hussain 2018). According to Indonesian Directorate of Fertilizers and Pesticides (2016), there are many active ingredients of herbicides used in paddy fields in Indonesian such as 2,4$\mathrm{D}$, metsulfuron-methyl, bispyribac sodium, fenoxaprop-pethyl, pendimethalin, and oxyfluorfen. However, 2,4-D and metsulfuron-methyl are two active compounds of herbicides that are commonly utilized in Indonesia.

The 2,4-D is a selective herbicide. It is utilized to control broadleaf weeds by disrupting hormone balance, auxin herbicide induces growth by cell elongation as opposed to cell division. Hormone interplay is important in the regulation of plant growth and development (Song 2014). Part-time of 2,4-D herbicide is relatively fast, an average of 10 days in the soil, and less than 10 days in water. However, it will be relatively long if the conditions are cold temperatures and moist soil (Chinalia et al. 2007). Metsulfuron-methyl is a systemic herbicide that inhibits the performance of acetolactate synthase enzyme (ALS) which can be applied pre-growth or post-growth. This herbicide is effective to control broadleaf and grass weeds which cause growth to stop after post-emergence application and will die within 7-21 days (Tomlin 2010).

Based on a survey conducted in Trimurjo paddy fields in Central Lampung Regency, Lampung, Indonesia, herbicide treatment was carried out intensively for more than 20 years for 2,4-D and more than 12 years for metsulfuron-methyl. It makes weeds were difficult to control with 2,4-D and metsulfuron-methyl herbicides. According to Kurniati (2018), vegetation analysis shows that $S$. zeylanica and $L$. octovalvis are the dominant weeds in Trimurjo paddy fields, Central Lampung Regency, Lampung, Indonesia. Based on this, it is necessary to test the resistance status and the different physiological activities of the existing weeds. Continued use of herbicides without any rotation of active ingredients in a long time causes resistant weeds. According to Ginting et al. (2015), resistant weeds also occur due to the application of excessive doses of herbicides. Herbicide resistance develops after a selection process that occurs over several generations.

The herbicide treatment causes differences in the physiological activity that occurs between resistant and susceptible weeds (Silva et al. 2017). According to Tcherkez and Limami (2019), the process of plant metabolism is correlated with the gas exchange that occurs. Gas exchange in plants can be measured to determine the rate of photosynthesis that occurs by measuring $\mathrm{CO}_{2}$ assimilation rate, stomatal conductance rate, and transpiration rate. 
Weed resistance trends in the world are increasing from year to year. Based on Heap (2020) it is known that worldwide in 1995 there were 192 resistant weed biotypes, increased to 337 biotypes in 2005 , then to 514 biotypes in 2020. Specifically, weeds resistant to 2,4-D (synthetic auxin) and metsulfuron-methyl (ALS inhibitor) herbicide increased from 10 and 13 in 1990 to 41 and 165 in 2020, respectively. Although the trend of weed resistance to herbicides in the world has increased sharply, the information about the development of weed resistance to herbicides in Indonesia is still very little. This certainly raises many questions because herbicides have been used intensively in Indonesia for more than 20 and 12 years. This study aims to determine the resistance status of $S$. zeylanica and L. octovalvis exposed to 2,4-D and metsulfuron-methyl herbicides and determine the difference of physiological activity in resistant and susceptible weeds to 2,4-D and metsulfuron-methyl herbicides.

\section{MATERIALS AND METHODS}

\section{Study area}

The study was conducted from August to December 2019. The research was conducted at The Greenhouse Botanical Garden of Sumatra Institute of Technology, Indonesia, Weed Science Laboratory of University of Lampung, Indonesia, and Integrated Laboratory of the Technology Innovation Centers of University of Lampung, Indonesia.

\section{Herbicide treatment on resistant status test}

This study used split-plot design with 6 treatments and 5 replications. The main plot was the origin of weeds (exposed to 2,4-D and metsulfuron-methyl herbicides) from Trimurjo, Central Lampung, Indonesia. Unexposed to 2,4-D and metsulfuron-methyl herbicides from Natar, South Lampung, Indonesia. Subplots are the dosage levels of 2,4-D $(0 ; 432.5 ; 865 ; 1,730 ; 3,460 ;$ and $6,920 \mathrm{~g} / \mathrm{ha})$ and metsulfuron-methyl $(0 ; 2 ; 4 ; 8 ; 16$; and $32 \mathrm{~g} / \mathrm{ha})$.

\section{Field survey and planting}

Field surveys were carried out in Trimurjo, Central Lampung, Indonesia which had long been exposed to 2,4-D and metsulfuron-methyl, and in Natar, South Lampung, Indonesia, which had never been exposed to herbicides. Weeds are taken in the form of seedlings and grown for uniform height and number of leaves. Seedling that has been taken from the field transplanted to a plastic pot with paddy media. Weeds are maintained until the vegetative phase.

\section{Herbicide application}

Weeds that have been planted and maintained are then selected based on the same level of uniformity. Before the herbicide application, the calibration was carried out using a red nozzle with a spray width of $2 \mathrm{~m}$ and a length of $5 \mathrm{~m}$, so that each experimental unit received the same amount of herbicide according to the treatment. The herbicide application is carried out in the morning starting from the lowest dose to the highest dose.

\section{Observation}

The variables observed in stage 1 were damage percent and biomass. Damage percent was determined by comparing weeds applied herbicide with untreated weeds (control). The comparisons observed were leaf color, changes in leaf shape, and abnormal growth. Percent damage was carried out by two observers in two replications. Observations were made at 2, 4, 6, 8, 10, 12, and 14 days after application (DAA). Harvesting was carried out at 14 DAA. Weeds were dried in an oven at $80^{\circ} \mathrm{C}$ for 48 hours until the biomass was constant.

\section{Data analysis}

Data analysis was conducted to determine; (i) Lethal Time $50 \%\left(\mathrm{LT}_{50}\right) . \mathrm{LT}_{50}$ is the required time to kill weeds by $50 \%$. $\mathrm{LT}_{50}$ was processed by probit analysis to obtain the value of damage percent. (ii) Effective Dose $50 \%\left(\mathrm{ED}_{50}\right)$. $\mathrm{ED}_{50}$ is the value that indicates the doses of herbicides that cause suppression by $50 \%$. The $\mathrm{ED}_{50}$ value is obtained from the conversion of weed biomass data into a percentage value of weed damage (Guntoro and Fitri 2013). (iii) Resistance Index (RI), which is the ratio value of $\mathrm{ED}_{50}$ of exposed and unexposed weeds. Based on the RI value of weeds, it can be seen resistance status. According to Ahmad-Hamdani et al. (2012), the resistance status can be determined by the criteria of the RI which is classified as susceptible if the RI is $<2$, low resistance if the RI is 2-6, moderate resistance if the $\mathrm{RI}>6-12$, and high resistance if the RI> 12 .

\section{Physiological activity analysis on resistant weed}

This study used split-plot design with 5 treatments and 5 replications. Weeds that have proven to be resistant and susceptible are replanted with the same method as herbicide treatment on resistant status test to observe their physiological activity analysis including carbon assimilation rate $\left(\mu \mathrm{mol} \mathrm{CO} \mathrm{CO}_{2}^{-2} \mathrm{~s}^{-1}\right)$, stomatal conductance rate $\left(\mathrm{mol} \mathrm{H}_{2} \mathrm{O} \mathrm{m}^{-2} \mathrm{~s}^{-1}\right)$, and transpiration rate $\left(\mathrm{mol} \mathrm{H}_{2} \mathrm{O}\right.$ $\mathrm{m}^{-2} \mathrm{~s}^{-1}$ ). The dosage level in stage 2 of 2,4-D were 0 ; $432.5 ; 865 ; 1,730$; and $3,460 \mathrm{~g} / \mathrm{ha}$. While the dosage level of metsulfuron-methyl were $0 ; 2 ; 4 ; 8$; and $16 \mathrm{~g} / \mathrm{ha}$. Weed physiological activity measurements were carried out using the Li-COR 6800 F (Portable Photosynthesis System).

\section{Planting and maintenance}

Weed species were have been proved resistant are planted and maintained until early vegetative phase with the same technique in resistant status test.

\section{Herbicide application}

The treatment was repeated in 5 replications in the same technique, plot size, and experimental design as herbicide treatment on resistant status test.

\section{Observation}

Physiological activity was observed at 4, 8, and 12 DAA. Weeds that are the object of observation for 
physiological activity are labeled with yellow labels on the second and third leaves that have been fully opened as a sign of leaf samples to be observed. Physiological activity test was carried out using a Li-COR $6800 \mathrm{~F}$ (Portable Photosynthesis System) to observe carbon assimilation, stomatal conductance, and transpiration rate.

\section{Data analysis}

The physiological activity data of resistant and susceptible weed were analyzed using standard error of mean, then a curve made to determine the differences of physiological activities between resistant and susceptible weed.

\section{RESULTS AND DISCUSSION}

\section{Resistance status of Spenochlea zeylanica to 2,4-D herbicide}

Damage percent of $S$. zeylanica exposed and unexposed to 2,4-D herbicide can be seen in Figure 1. At doses: 432.5; $865 ; 1,730 ; 3,460 ;$ and $6,920 \mathrm{~g} / \mathrm{ha}, S$. zeylanica from exposed and unexposed areas of 2,4-D herbicide began damage at 2 DAA and continued to increase until 14 DAA. Damage percent of $S$. zeylanica from the unexposed area is higher than the exposed area in all doses tested (432.5$6,920 \mathrm{~g} / \mathrm{ha})$. Synthetic auxin herbicide (2,4-D) causes uncontrolled and disorganized plant growth finally killing unexposed weeds, e.g. broadleaf weeds (Schütte et al. 2017). Exposed weeds have the ability to survive against the herbicide (Chinalia et al. 2007). The results of this study are in line with the research of Prakoso (2018) which states that the application of herbicides causes higher damage in unexposed weeds compared to exposed weeds. The higher dose of herbicide causes faster $\mathrm{LT}_{50}$ (Table 1). At dose tested, $\mathrm{LT}_{50}$ of $S$. zeylanica is higher than $\mathrm{LT}_{50}$ of $S$. zeylanica unexposed. Figueiredo et al. (2018) state that in the mechanism of action, resistant weeds can metabolize herbicides faster than susceptible weeds. These results lead to different times for herbicide to poison resistant and susceptible weeds.

The higher dose of herbicide causes a higher damage percent and lower biomass (Figure 2). The damage percent of $S$. zeylanica exposed to 2,4-D is lower than unexposed to $2,4-\mathrm{D}$, so the biomass value of $S$. zeylanica exposed is higher than unexposed to 2,4-D. Weeds that are continuously applied with herbicides can develop resistance to herbicides. This causes a decrease in damage percent and increased biomass. These results are in line with Bernards et al. (2012) which shows the damage and biomass of Amaranthus tuberculatus resistant to 2,4-D herbicide is higher than susceptible weeds. The $\mathrm{ED}_{50}$ value of $S$. zeylanica exposed and unexposed to 2,4-D was respectively 313.58 and $142.91 \mathrm{~g} /$ ha (Table 2), so the RI values of $S$. zeylanica exposed were 2.19 and considered as having low resistance to 2,4-D. Herbicide translocation compartmentation (restricted herbicide movements) can cause weed resistance. Rey-Caballero et al. (2016) state that 2,4-D herbicide causes inhibition of herbicide movement, so it cannot reach its target location in sufficient numbers of molecules to cause death.

Table 1. Lethal Time 50\% (LT50) value of S. zeylanica due to 2,4D herbicide

\begin{tabular}{|c|c|c|c|c|}
\hline \multirow{2}{*}{$\begin{array}{c}\text { Dose } \\
\text { (g/ha) }\end{array}$} & \multirow{2}{*}{ Weeds } & \multirow{2}{*}{ Regression } & \multicolumn{2}{|c|}{$\mathbf{L T}_{50}$ (days) } \\
\hline & & & Exposed & Unexposed \\
\hline \multirow[t]{2}{*}{432.5} & Exposed & $\mathrm{y}=2.93 \mathrm{x}+2.02$ & 10.34 & \\
\hline & Unexposed & $y=3.14 x+2.17$ & & 7.97 \\
\hline \multirow[t]{2}{*}{865} & Exposed & $y=3.38 x+1.95$ & 7.97 & \\
\hline & Unexposed & $y=3.95 x+1.87$ & & 6.21 \\
\hline \multirow[t]{2}{*}{1,730} & Exposed & $y=3.68 x+1.89$ & 6.99 & \\
\hline & Unexposed & $y=5.58 x+1.11$ & & 4.99 \\
\hline \multirow[t]{2}{*}{3,460} & Exposed & $y=4.08 x+1.75$ & 6.25 & \\
\hline & Unexposed & $y=6.17 x+0.98$ & & 4.54 \\
\hline \multirow[t]{2}{*}{6,920} & Exposed & $y=5.66 x+1.10$ & 4.90 & \\
\hline & Unexposed & $\mathrm{y}=5.93 \mathrm{x}+1.29$ & & 4.23 \\
\hline
\end{tabular}

Note: $\mathrm{x}=\log$ day of observation; $\mathrm{y}=$ probit value of damage percent; $\mathrm{LT}_{50}=$ anti $\log$ of $\mathrm{x}$ value .

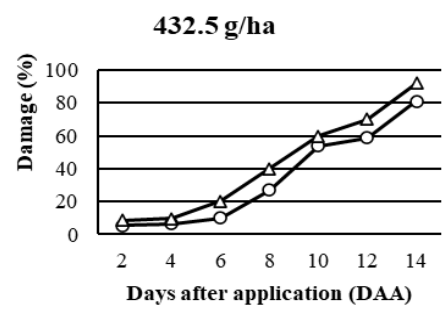

A

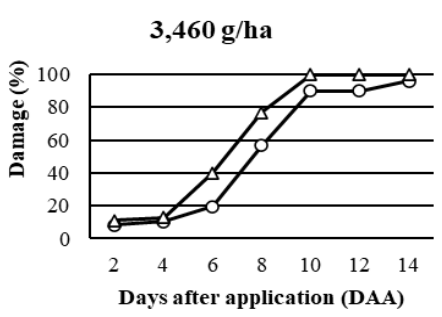

D

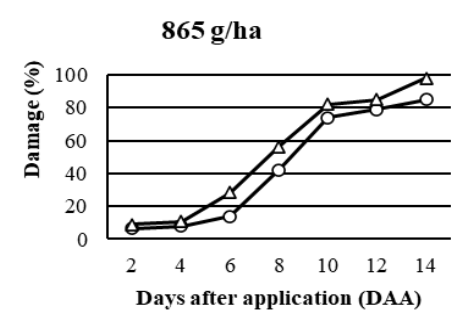

B

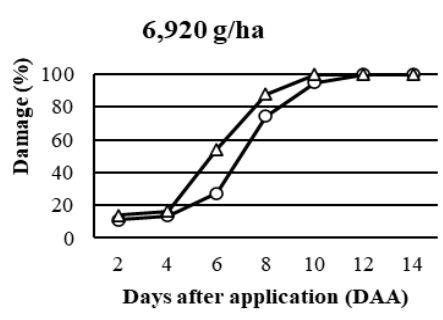

$\mathbf{E}$

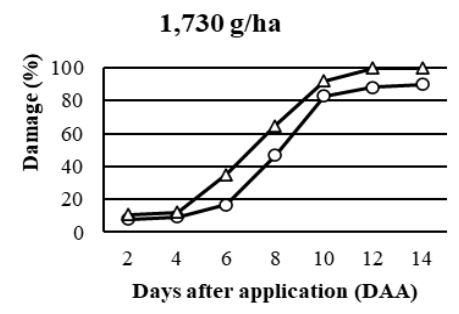

C

Figure 1. Damage of Spenochlea zeylanica due to 2,4-D herbicide. Note: $-0-=$ exposed, $\triangle-\triangle=$ unexposed 
Table 2. Effective Dose 50\% (ED $\left.\mathrm{ED}_{50}\right)$ value and Resistance Index (RI) of S. zeylanica due to 2,4-D herbicide

\begin{tabular}{|c|c|c|c|}
\hline Weeds & $\begin{array}{l}\text { ED50 } \\
\text { (g/ha) }\end{array}$ & $\begin{array}{l}\text { Resistance } \\
\text { index }\end{array}$ & $\begin{array}{l}\text { Classification of resistance status } \\
\text { (Ahmad-Hamdani et al. 2012) }\end{array}$ \\
\hline Exposed & 313.58 & 2.19 & Low Resistance \\
\hline
\end{tabular}

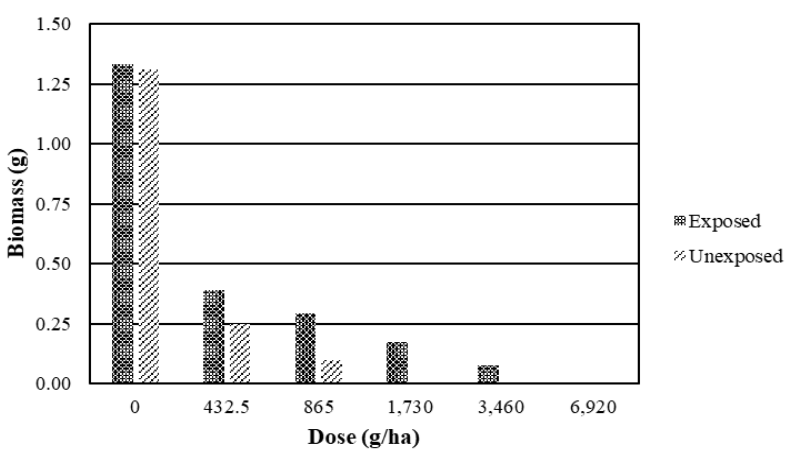

Figure 2. Biomass of $S$. zeylanica due to 2,4-D herbicide at 14 DAA

\section{Resistance status of Ludwigia octovalvis to 2,4-D herbicide}

Ludwigia octovalvis exposed has the same damage percent at 14 DAA as L. octovalvis unexposed at the 2,4-D dose: $432.5 ; 865 ; 1,730 ; 3,460$; and $6,920 \mathrm{~g} /$ ha (Figure 3 ). Application of herbicide 2,4-D to weeds can cause the production of ethylene and abscisic acid to increase. Ethylene is needed by plants to accelerate fruit ripening.
Abscisic acid is needed by plants for stomatal conductance. Excessive ethylene production and intracellular accumulation of abscisic acid (ABA) are known to cause a toxic response that triggers a metabolic stress response reaction resulting in permanent damage (Chinalia et al. 2007). This shows L. octovalvis exposed gives the same response as $L$. octovalvis unexposed. The results of $\mathrm{LT}_{50}$ (Table 3) show that there were no significant differences between $L$. octovalvis exposed and unexposed to 2,4-D herbicide. L. octovalvis exposed is still susceptible to 2,4-D herbicide. According to Chinalia et al. (2007), Application of 2,4-D herbicide to susceptible weeds causes disruption of hormonal balance, so division and expansion of cell will be inhibited which results in death.

The results of biomass (Figure 4) show that there was no biomass at 14 DAA, because L. octovalvis exposed and unexposed had died since 10-14 DAA. These results are in line with Crespo et al. (2017) which showed that $A$. tuberculatus susceptible 2,4-D has much lower biomass than A. tuberculatus resistant 2,4-D. Table 4 shows that $\mathrm{ED}_{50}$ of L. octovalvis exposed and unexposed to 2,4-D herbicide showed the same result $(84.92 \mathrm{~g} / \mathrm{ha})$, so the RI value of $L$. octovalvis exposed was 1.00 . Based on the value of the RI, L. octovalvis exposed was classified as susceptible to 2,4-D. This is caused by 2,4-D herbicides induce growth by cell elongation and cell division. Hormone interplay is important in the regulation of plant growth and development (Aviles-Arnaut and Delano-Frier 2012; Xu et al. 2013). Unlike natural auxins, which are rapidly degraded by plants 2,4-D last for a long time resulting in the overproduction of ethylene which may result in a number of herbicide-related responses, including epinasty and senescence (Song 2014).

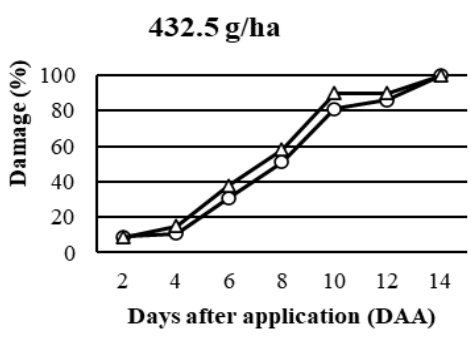

A

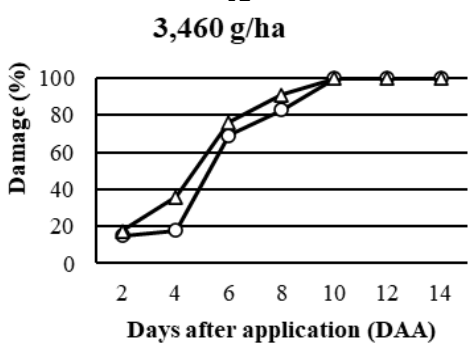

D

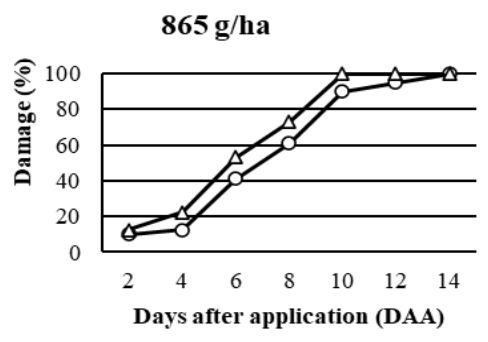

B

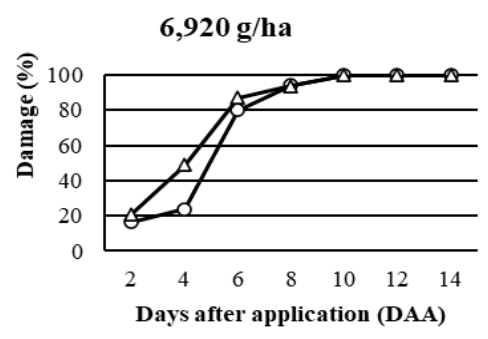

$\mathbf{E}$

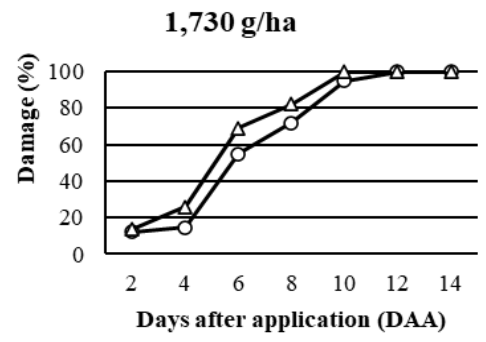

C

Figure 3. Damage of L. octovalvis due to 2,4-D herbicide. Note: $\multimap-$ exposed, $\triangle-=$ unexposed 


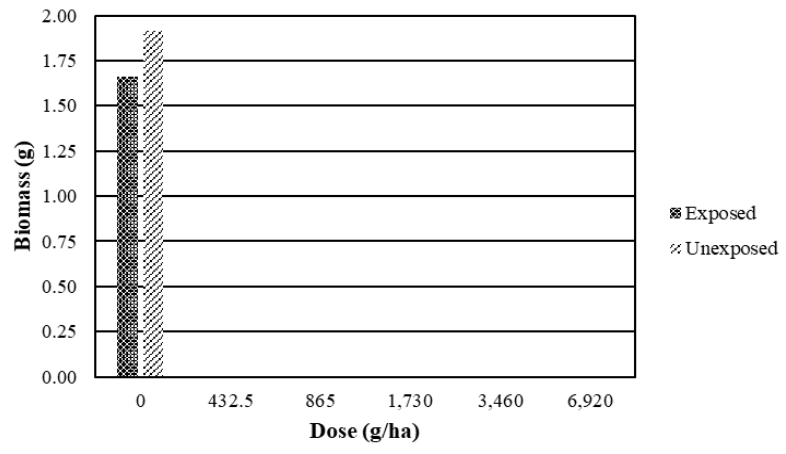

Figure 4. Biomass of L. octovalvis due to 2,4-D herbicide at 14 DAA

Table 3. $\mathrm{LT}_{50}$ value of $L$. octovalvis due to 2,4-D herbicide

\begin{tabular}{|c|c|c|c|c|}
\hline \multirow{2}{*}{$\begin{array}{l}\text { Dose } \\
\text { (g/ha) }\end{array}$} & \multirow{2}{*}{ Weeds } & \multirow{2}{*}{ Regression } & \multicolumn{2}{|c|}{$\mathbf{L T}_{50}$ (days) } \\
\hline & & & Exposed & Unexposed \\
\hline \multirow[t]{2}{*}{432.5} & Exposed & $y=4.55 x+1.51$ & 5.85 & \\
\hline & Unexposed & $y=4.70 x+1.55$ & & 5.42 \\
\hline \multirow[t]{2}{*}{865} & Exposed & $y=4.84 x+1.50$ & 5.28 & \\
\hline & Unexposed & $y=5.83 x+1.31$ & & 4.29 \\
\hline \multirow[t]{2}{*}{1,730} & Exposed & $y=5.50 x+1.34$ & 4.63 & \\
\hline & Unexposed & $y=5.73 x+1.53$ & & 4.04 \\
\hline \multirow[t]{2}{*}{3,460} & Exposed & $y=5.80 x+1.44$ & 4.11 & \\
\hline & Unexposed & $y=5.49 x+1.87$ & & 3.71 \\
\hline \multirow[t]{2}{*}{6,920} & Exposed & $y=5.69 x+1.71$ & 3.79 & \\
\hline & Unexposed & $y=5.21 x+2.26$ & & 3.36 \\
\hline
\end{tabular}

Note: $\mathrm{x}=\log$ day of observation; $\mathrm{y}=$ probit value of damage percent; $\mathrm{LT}_{50}=$ anti $\log$ of $\mathrm{x}$ value

Table 4. $\mathrm{ED}_{50}$ value and RI of $L$. octovalvis due to 2,4-D herbicide

\begin{tabular}{|c|c|c|c|}
\hline Weeds & $\begin{array}{c}\text { EDs0 } \\
\text { (g/ha) }\end{array}$ & $\begin{array}{l}\text { Resistance } \\
\text { index }\end{array}$ & $\begin{array}{l}\text { Classification of resistance status } \\
\text { (Ahmad-Hamdani et al. 2012) }\end{array}$ \\
\hline Exposed & 84.92 & 1.00 & Susceptible \\
\hline Unexposed & 84.92 & & \\
\hline
\end{tabular}

\section{Resistance status of Spenochlea zeylanica to metsulfuron-methyl herbicide}

Damage percent of $S$. zeylanica exposed to metsulfuronmethyl herbicide is below than the damage of $S$. zeylanica unexposed to metsulfuron-methyl herbicide (Figure 5). This indicates that the damage of $S$. zeylanica exposed was significantly slower compared to $S$. zeylanica unexposed. The metsulfuron-methyl herbicide at dose 2, 4, 8, and 16 $\mathrm{g} /$ ha were unable to control $S$. zeylanica exposed. This occurs due to the inability of the herbicide molecules to affect the performance of ALS/AHAS enzyme. The same result was shown by Costa and Rizzardi (2014) which stated that Raphanus raphanistrum susceptible to metsulfuronmethyl (ALS/AHAS inhibitor) had a much lower damage percent compared to $R$. raphanistrum resistance. The higher dose causes faster $\mathrm{LT}_{50}$ (Table 5). At $4 \mathrm{~g} / \mathrm{ha}$, the $\mathrm{LT}_{50}$ value of $S$. zeylanica exposed was 22.11 days, while $S$. zeylanica unexposed was 6.23 days. Also, at another dose of metsulfuron-methyl, $\mathrm{LT}_{50}$ value of $S$. zeylanica exposed to higher than $S$. zeylanica unexposed. This shows that metsulfuron-methyl requires more time to poison $S$. zeylanica exposed compared to $S$. zeylanica unexposed.

Table 5. $\mathrm{LT}_{50}$ value of $S$. zeylanica due to metsulfuron-methyl herbicide

\begin{tabular}{|c|c|c|c|c|}
\hline \multirow{2}{*}{$\begin{array}{l}\text { Dose } \\
\text { (g/ha) }\end{array}$} & \multirow{2}{*}{ Weeds } & \multirow{2}{*}{ Regression } & \multicolumn{2}{|c|}{ LT $_{50}$ (days) } \\
\hline & & & Exposed & Unexposed \\
\hline \multirow[t]{2}{*}{2} & Exposed & $y=1.77 x+2.42$ & 28.78 & \\
\hline & Unexposed & $y=3.85 x+1.67$ & & 5.77 \\
\hline \multirow[t]{2}{*}{4} & Exposed & $y=1.75 x+2.65$ & 22.11 & \\
\hline & Unexposed & $y=4.27 x+1.61$ & & 5.38 \\
\hline \multirow[t]{2}{*}{8} & Exposed & $y=1.92 x+2.66$ & 16.50 & \\
\hline & Unexposed & $y=4.50 x+1.62$ & & 5.09 \\
\hline \multirow[t]{2}{*}{16} & Exposed & $y=2.34 x+2.47$ & 12.15 & \\
\hline & Unexposed & $y=5.45 x+1.26$ & & 4.85 \\
\hline \multirow[t]{2}{*}{32} & Exposed & $y=4.33 x+1.45$ & 6.54 & \\
\hline & Unexposed & $y=6.01 x+1.16$ & & 4.35 \\
\hline
\end{tabular}

Note: $\mathrm{x}=\log$ day of observation; $\mathrm{y}=$ probit value of damage percent; $\mathrm{LT}_{50}=$ anti $\log$ of $\mathrm{x}$ value

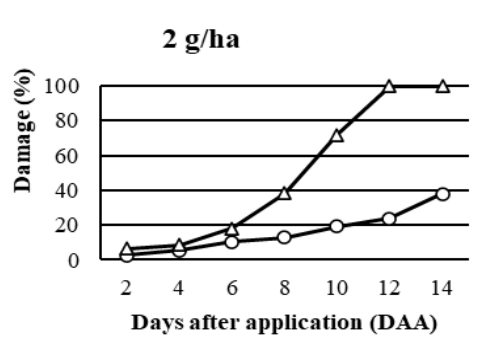

A

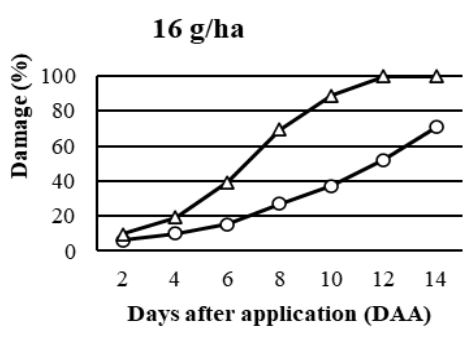

D

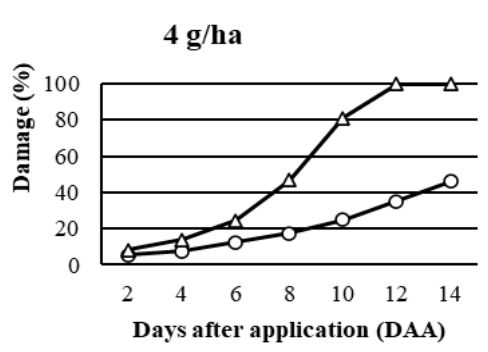

B

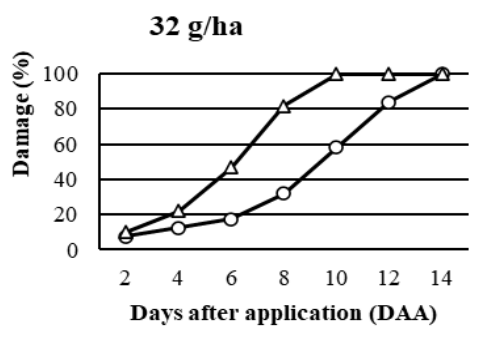

$\mathbf{E}$

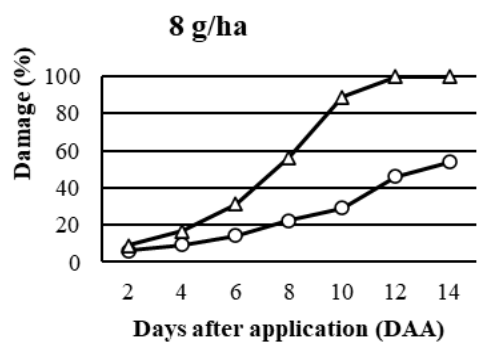

C

Figure 5. Damage of S. zeylanica due to metsulfuron-methyl herbicide. Note: $\multimap-=$ exposed, $\triangle-=$ unexposed 


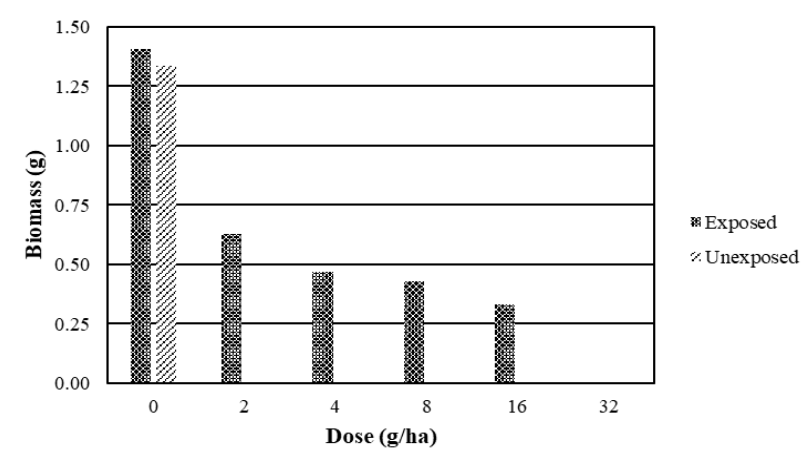

Figure 6. Biomass of $S$. zeylanica due to metsulfuron-methyl herbicide at 14 DAA

The results of biomass (Figure 6) show that S. zeylanica exposed to metsulfuron-methyl continues to decrease with increasing doses until death at $32 \mathrm{~g} / \mathrm{ha}$, whereas $S$. zeylanica unexposed to metsulfuron-methyl did not have biomass because had died at 14 DAA. S. zeylanica exposed has a higher biomass when compared to $S$. zeylanica unexposed. This is consistent with the results of research by McCullough et al. (2016) which states the occurrence of resistance to ALS herbicide affects to biomass. Table 6 states that the $\mathrm{ED}_{50}$ value of $S$. zeylanica exposed was 5.72 $\mathrm{g} / \mathrm{ha}$, while $S$. zeylanica unexposed was $1.99 \mathrm{~g} / \mathrm{ha}$, so the RI value of $S$. zeylanica exposed was 2.87 . Based on the RI, $S$. zeylanica exposed classified as low resistance to metsulfuron-methyl. The results of this study are in line with the research of Prakoso (2018) which shows $S$. zeylanica has been resistant to metsulfuron-methyl herbicide in the paddy field of Central Lampung, Indonesia. This resistance occurs because $S$. zeylanica exposed can metabolize metsulfuron-methyl molecules.
This was confirmed by Lu et al. (2019) which states that resistant weeds have increased metabolism of herbicides. As a result, herbicide translocation levels are lower, so the damage can be prevented.

\section{Resistance status of Ludwigia octovalvis to metsulfuron- methyl herbicide}

Ludwigia octovalvis exposed has the same damage percent as L. octovalvis unexposed (Figure 7). L.octovalvis exposed or unexposed cannot metabolize herbicides, causing symptoms of damage. Hall et al. (2014) stated that some weeds that are resistant to herbicides can quickly degrade or metabolize herbicides in the form of non-toxic compounds, while susceptible weeds do not have this ability and herbicides are still compounds that are toxic to weeds. There were no significant differences in $\mathrm{LT}_{50}$ between $L$. octovalvis exposed and unexposed metsulfuronmethyl herbicide (Table 7). This is due to symptoms in the form of leaf necrosis and chlorosis experienced by $L$. octovalvis exposed and not exposed which causes disruption of amino acid synthesis. According to Zhou et al. (2007) the mechanism of action of ALS inhibitors, such as disruption of synthesis of branched-chain amino acids, disruption of photosynthesis transport and respiration system, elicit lots of disputes, which have also been implicated in the mechanism of plant death.

Table 6. ED50 value and RI of $S$. zeylanica due to metsulfuronmethyl herbicide

\begin{tabular}{|c|c|c|c|}
\hline Weeds & $\begin{array}{l}\text { ED }_{50} \\
\text { (g/ha) }\end{array}$ & $\begin{array}{l}\text { Resistance } \\
\text { index }\end{array}$ & $\begin{array}{l}\text { Classification of resistance status } \\
\text { (Ahmad-Hamdani et al. 2012) }\end{array}$ \\
\hline Exposed & 5.72 & 2.87 & Low resistance \\
\hline Unexposed & 1.99 & & \\
\hline
\end{tabular}

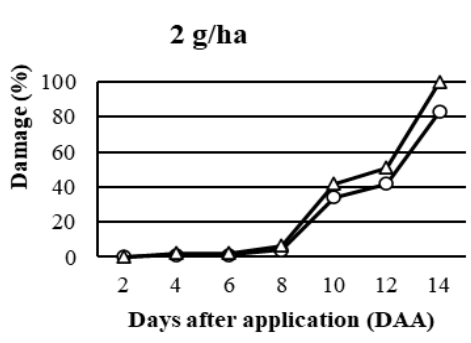

A

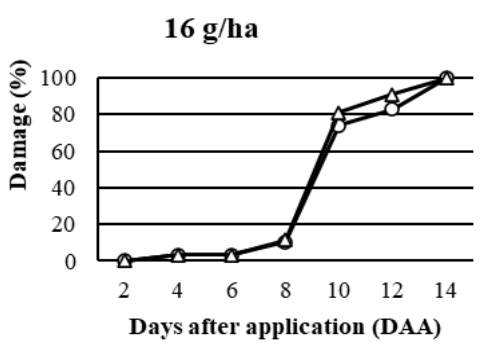

D

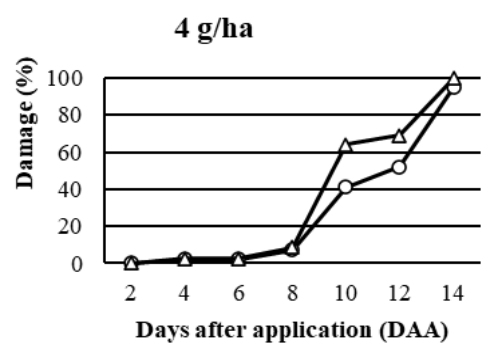

B

$32 \mathrm{~g} / \mathrm{ha}$

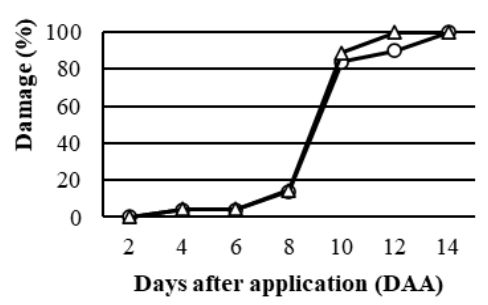

E

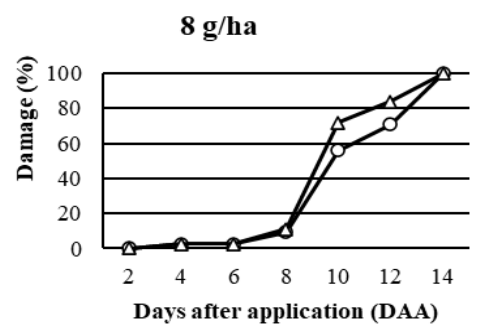

C

Figure 7. Damage of L. octovalvis due to metsulfuron-methyl herbicide. Note: $\multimap-=$ exposed, $\triangle \backsim=$ unexposed 
Table 7. $\mathrm{LT}_{50}$ value of $L$. octovalvis due to metsulfuron-methyl herbicide

\begin{tabular}{|c|c|c|c|c|}
\hline \multirow{2}{*}{$\begin{array}{c}\text { Dose } \\
\text { (g/ha) }\end{array}$} & \multirow{2}{*}{ Weeds } & \multirow{2}{*}{ Regression } & \multicolumn{2}{|c|}{ LT $_{50}$ (days) } \\
\hline & & & Exposed & Unexposed \\
\hline \multirow[t]{2}{*}{2} & Exposed & $\mathrm{y}=6.29 x-1.79$ & 3.24 & \\
\hline & Unexposed & $y=7.60 x-2.39$ & & 2.20 \\
\hline \multirow[t]{2}{*}{4} & Exposed & $y=6.77 x-1.91$ & 2.86 & \\
\hline & Unexposed & $y=8.02 x-2.56$ & & 2.02 \\
\hline \multirow[t]{2}{*}{8} & Exposed & $y=7.98 x-2.55$ & 2.03 & \\
\hline & Unexposed & $y=8.33 x-2.69$ & & 1.89 \\
\hline \multirow[t]{2}{*}{16} & Exposed & $y=8.27 x-2.62$ & 1.94 & \\
\hline & Unexposed & $y=8.52 x-2.72$ & & 1.85 \\
\hline \multirow[t]{2}{*}{32} & Exposed & $y=8.51 x-2.66$ & 1.88 & \\
\hline & Unexposed & $y=9.42 x-3.11$ & & 1.59 \\
\hline
\end{tabular}

Note: $\mathrm{x}=\log$ day of observation; $\mathrm{y}=$ probit value of poisoning percent; $\mathrm{LT}_{50}=$ anti $\log$ of $\mathrm{x}$ value

Table 8. ED50 value and RI of $L$. octovalvis due to metsulfuronmethyl herbicide

\begin{tabular}{|c|c|c|c|}
\hline Weeds & $\begin{array}{l}\text { ED } \\
\text { (g/ha) }\end{array}$ & $\begin{array}{l}\text { Resistance } \\
\text { index }\end{array}$ & $\begin{array}{l}\text { Classification of resistance status } \\
\text { (Ahmad-Hamdani et al. 2012) }\end{array}$ \\
\hline Exposed & 3.17 & 1.59 & Susceptible \\
\hline Unexposed & 1.99 & & \\
\hline
\end{tabular}

There was no biomass at dose 8-32 $\mathrm{g} / \mathrm{ha}$, this is because L. octovalvis exposed and unexposed have died at 14 DAA (Figure 8). In Figure 7, L.octovalvis exposed showed damage percent of 83 and $95 \%$ at doses of 2 and $4 \mathrm{~g} / \mathrm{ha}$. This shows that L.octovalvis exposed was still alive at 14 DAA. At doses 2 and $4 \mathrm{~g} / \mathrm{ha}$ L.octovalvis exposed had biomass of 0.23 and $0.17 \mathrm{~g}$, whereas L.octovalvis unexposed did not have biomass because they had died at 14 DAA (Figure 8). Similar results also reported by Singh et al. (2015) who stated application of metsulfuron-methyl herbicide causes lower biomass on broadleaf. Metsulfuronmethyl is a selective systemic herbicide absorbed through the roots and foliages with rapid translocation. In susceptible plants, it inhibits branched-chain amino acid synthesis (ALS or AHAS) and interferes in biosynthesis of valine and isoleucine stopping cell division and plant growth (Banga and Yadav 2004; Singh and Singh 2005). $\mathrm{ED}_{50}$ value of $L$. octovalvis exposed was $3.17 \mathrm{~g} / \mathrm{ha}$, while $\mathrm{ED}_{50}$ value of $L$. octovalvis unexposed was $1.99 \mathrm{~g} / \mathrm{ha}$, so the RI value of $L$. octovalvis exposed was 1.59 (Table 8). Based on the value of the RI, L. octovalvis exposed was classified as susceptible to metsulfuron-methyl.

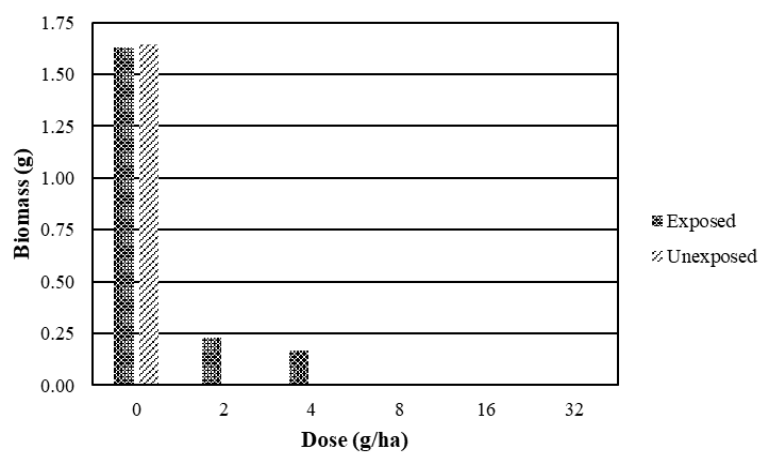

Figure 8. Biomass of L. octovalvis due to metsulfuron-methyl herbicide at 14 DAA

\section{Physiological activity of resistant Spenochlea zeylanica to the 2,4-D herbicide}

The results show that carbon assimilation rate (Figure 9), stomatal conductance rate (Figure 10), and transpiration rate (Figure 11) of $S$. zeylanica resistant to 2,4-D herbicide at dose: $432.5 ; 865$; and $1,730 \mathrm{~g} / \mathrm{ha}$ were higher than $S$. zeylanica susceptible to 2,4-D herbicide at 4,8 , or 12 DAA. Stomatal conductance affects the process of carbon assimilation and transpiration (Nascentes et al. 2017). Figure 9 shows the difference in stomata conductance rate, involve the carbon assimilation rate and transpiration rate of $S$. zeylanica susceptible to be lower than $S$. zeylanica resistant. According to Tcherkez and Limami (2019), the process of plant metabolism is correlated with the gas exchange that occurs. Gas exchange in plants can be measured to determine the rate of photosynthesis that occurs by measuring $\mathrm{CO}_{2}$ assimilation rate, stomatal conductance rate, and transpiration rate. According to Dusenge et al. (2019), $\mathrm{CO}_{2}$ is very influential on the rate of photosynthesis, so an increase in $\mathrm{CO}_{2}$ is expected to increase the rate of photosynthesis. One of the parameters for observing physiological activity in weeds is stomatal conductance (Silva et al. 2017). Application 2,4-D herbicide can cause an increase in ethylene. The effects of increased ethylene concentrations in plants are leaf epinasty, tissue swelling, and plant senescence, as well as being the trigger for an increase in the production of abscisic acid (ABA). Increased levels of this hormone promote stomata closing, which limits transpiration and carbon assimilation (Christoffoleti et al. 2015). 


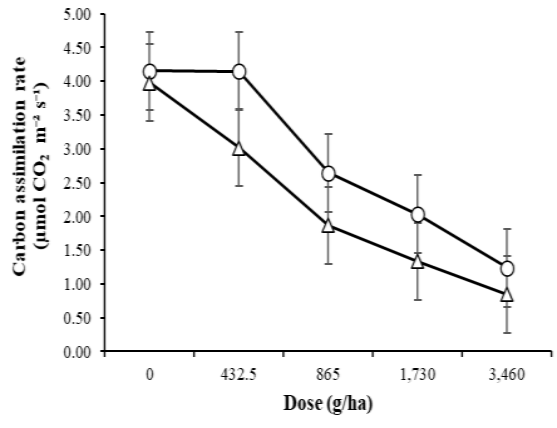

A

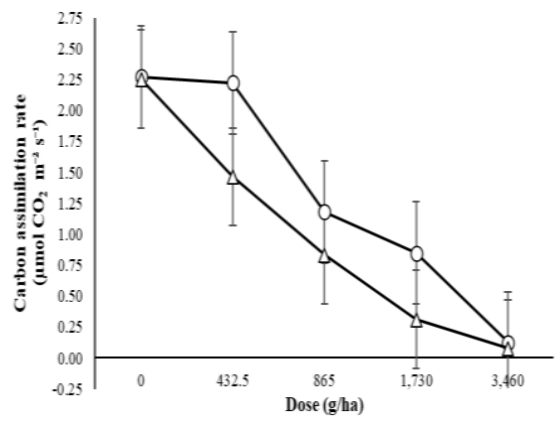

B

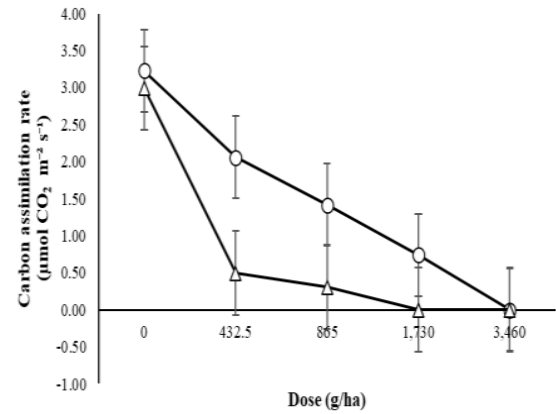

C

Figure 9. Carbon assimilation rate of S. zeylanica resistant to $2,4-\mathrm{D}$ herbicide. Note: $-\mathbf{-}-\mathbf{r e s i s t a n t ,}-\Delta-=$ susceptible, DAA $=$ Days After Application. A. 4 DAA, B. 8 DAA, C. 12 DAA

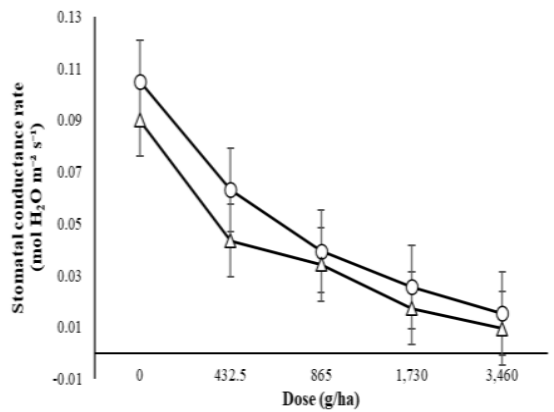

A

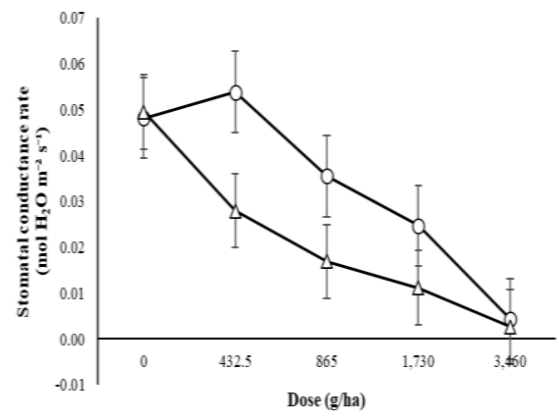

B

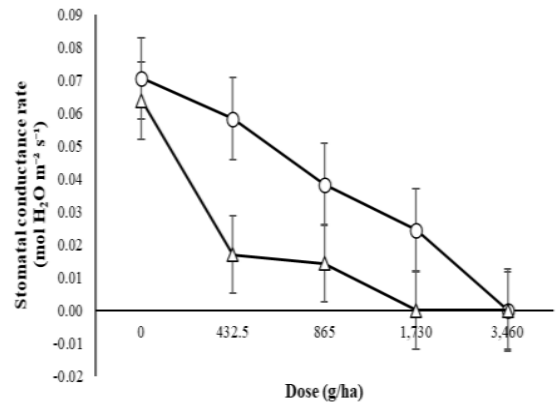

C

Figure 10. Stomatal conductance rate of $S$. zeylanica resistant to 2,4-D herbicide. Note: $-0-=$ resistant, $-\Delta-=$ susceptible, DAA $=$ Days After Application. A. 4 DAA, B. 8 DAA, C. 12 DAA

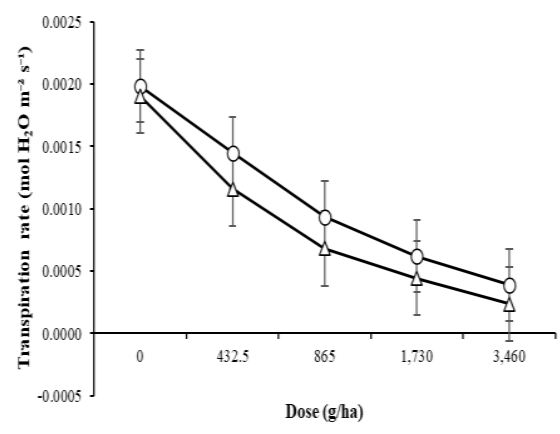

A

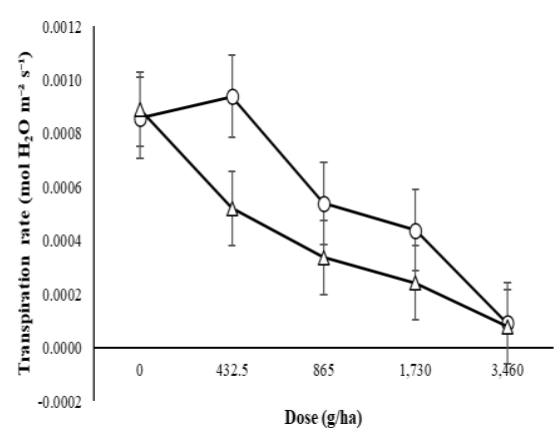

B

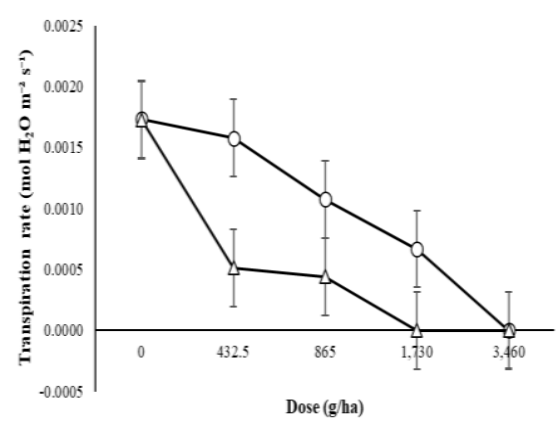

C

Figure 11. Transpiration rate of $S$. zeylanica resistant to $2,4-\mathrm{D}$ herbicide. Note: $-0-=$ resistant, $-\Delta-=$ susceptible, DAA $=$ Days After Application. A. 4 DAA, B. 8 DAA, C. 12 DAA

\section{Physiological activity of resistant Spenochlea zeylanica to metsulfuron-methyl herbicide}

The results show that carbon assimilation rate (Figure 12), stomatal conductance rate (Figure 13), and transpiration rate (Figure 14) of S. zeylanica resistant to metsulfuron-methyl herbicide (ALS inhibitor) at doses of 2, 4,8 , and $16 \mathrm{~g} / \mathrm{ha}$ is higher $S$. zeylanica susceptible either at 4,8 or 12 DAA. Similar results were also shown by research by Rodrigues et al. (2014) state that the application of the herbicide nicosulfuron (ALS inhibitor) to the Urochloa brizantha had an impact on decreased physiological activity (photosynthesis, stomatal conductance, and transpiration). The results of this study indicate that the higher dose of metsulfuron-methyl herbicide results in a lower carbon assimilation rate, stomatal conductance rate, and transpiration rate. Stomatal conductance functions as a regulator of the rate of transpiration that plays a role in the absorption of water and nutrients in the soil and regulates leaf temperature (Messinger et al. 2006). According to Usui and Kasubuchi 
(2011), the application of herbicides disrupts turgor pressure on the guard cell to regulate the opening of the stomata which results in carbon exchange and transpiration being inhibited. This results in decreased photosynthesis which results in death. The same results were shown by Yuan et al. (2013) which stated that the higher dosage of sulfonylurea herbicide (mesosulfuron-methyl and iodosulfuron-methyl sodium) on Radix Isatidis (Isatis indigotica Fort.) caused the stomata conductance rate and transpiration rate to decrease and resulted in a decrease in photosynthesis rate.
In conclusion, S. zeylanica from paddy field area use herbicide for a long time shows low-level resistance to 2,4$\mathrm{D}$ and metsulfuron-methyl herbicides with resistance index (RI) were respectively 2.19 and 2.87 . While exposed $L$. octovalvis was still classified as susceptible to 2,4-D and metsulfuron-methyl herbicides with RI were respectively 1.00 and 1.59. The physiological activities (carbon assimilation rate, stomatal conductance rate, and transpiration rate) of $S$. zeylanica resistant to 2,4-D and metsulfuron-methyl herbicides is higher than $S$. zeylanica susceptible 2,4-D and metsulfuron-methyl herbicides.

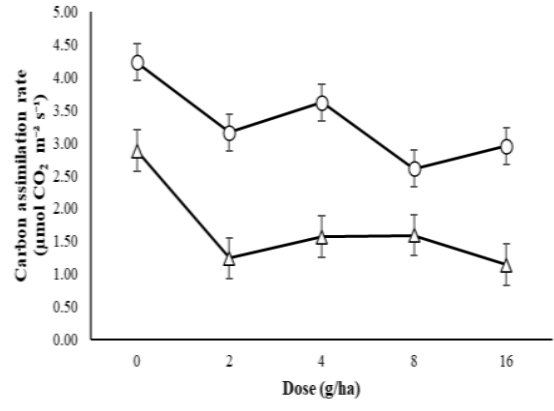

A

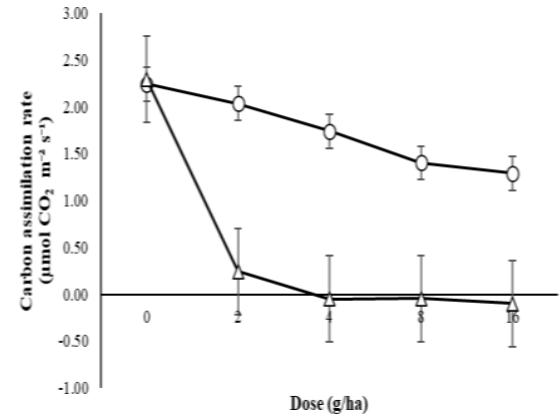

B

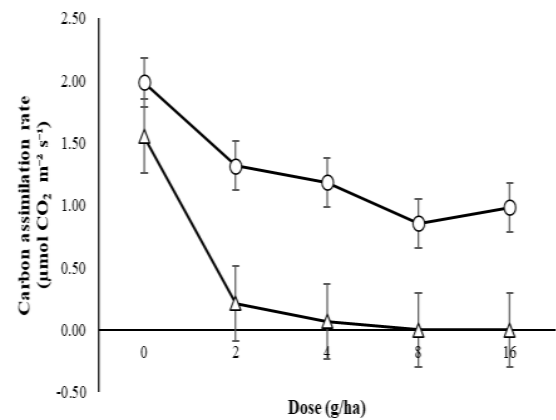

C

Figure 12. Carbon assimilation rate of $S$. zeylanica resistant to metsulfuron-methyl herbicide. Note: $\longrightarrow--=$ resistant, $-\triangle-=$ susceptible, DAA = Days After Application. A. 4 DAA, B. 8 DAA, C. 12 DAA

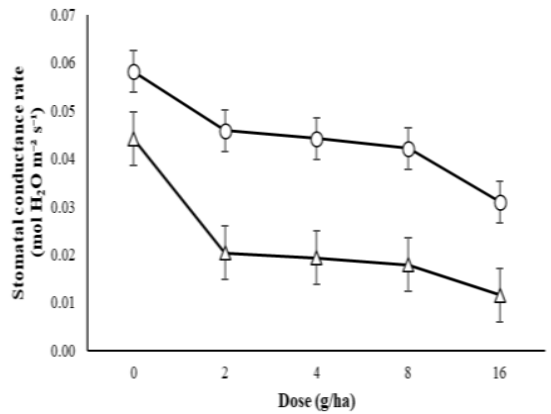

A

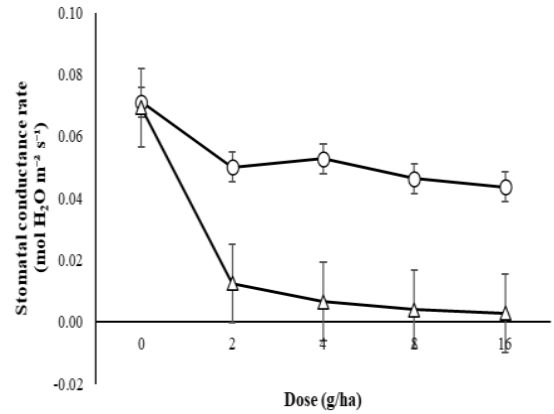

B

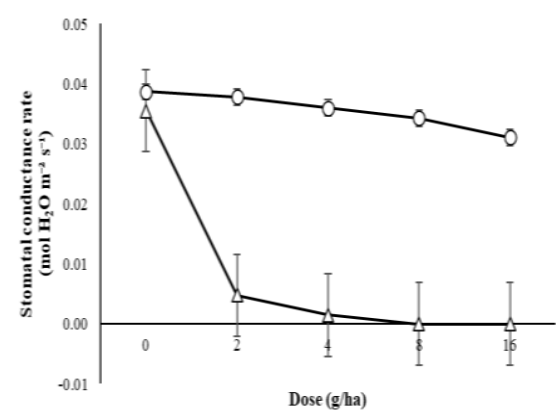

C

Figure 13. Stomatal conductance rate of $S$. zeylanica resistant to metsulfuron-methyl herbicide. Note: $\longrightarrow-\mathbf{0}=$ resistant, $\triangle-=$ susceptible, DAA = Days After Application. A. 4 DAA, B. 8 DAA, C. 12 DAA

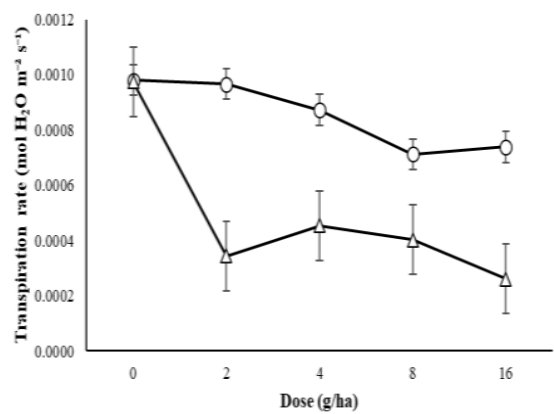

A

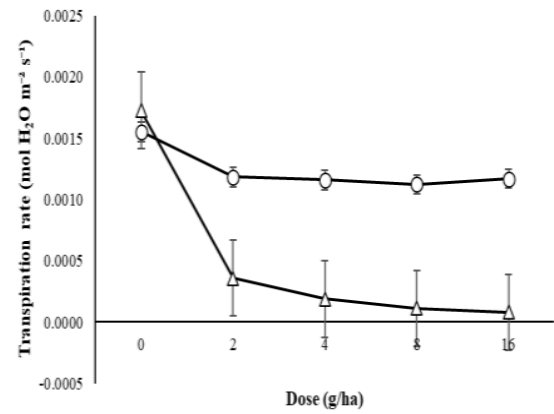

B

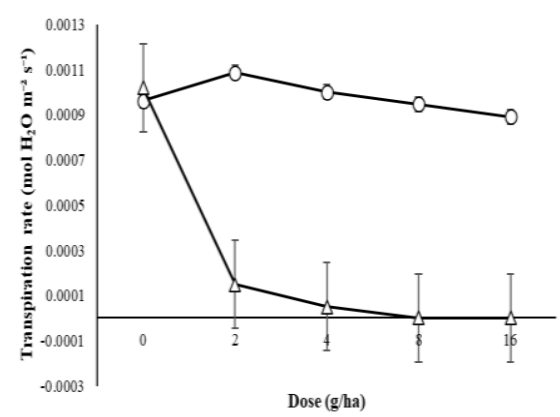

C

Figure 14. Transpiration rate of $S$. zeylanica resistant to metsulfuron-methyl herbicide. Note: $-\mathbf{-}-=$ resistant, $-\Delta-=$ susceptible, DAA = Days After Application. A. 4 DAA, B. 8 DAA, C. 12 DAA 


\section{ACKNOWLEDGEMENTS}

This research was funded by University of Lampung, Indonesia through Graduate School Competitive Grant. Special thanks to to the Greenhouse Botanical Garden of Sumatra Institute of Technology, the Weed Science Laboratory University of Lampung, and the Integrated Laboratory of the Technology Innovation Centers University of Lampung. The authors also gratefully acknowledge helpful comments and advice from the reviewers. However, views expressed are those of the authors alone.

\section{REFERENCES}

Abouziena HF, Haggag WM. 2016. Weed control in clean agriculture: a review. Planta Daninha 34 (2): 377-392. DOI: 10.1590/S010083582016340200019.

Ahmad-Hamdani MS, Owen MJ, Yu Q, Powles SB. 2012. ACCase inhibiting herbicide-resistant Avena spp. populations from the Western Australian grain belt. Weed Technol 26 (1): 130-136. DOI: $10.1614 /$ wt-d-11-00089.1.

Aviles-Arnaut H, Delano-Frier JP. 2012. Characterization of the tomato prosystemin promoter: organ-specific expression, hormone specificity and methyl jasmonate responsiveness by deletion analysis in transgenic tobacco plants. J Integr Plant Biol 54: 15-32. DOI: $10.1111 / j .1744-7909.2011 .01084 . x$

Banga RS, Yadav A. 2004. Effect of fenoxaprop and sulfosulfuron alone and as tank mixture against complex flora of weeds in wheat. Indian J Weed Sci 36: 163-65.

Bernards ML, Crespo RJ, Kruger GR, Gaussoin R, Tranel PJ. 2012. A waterhemp (Amaranthus tuberculatus) population resistant to 2,4-D. Weed Scil 60: 379-384. DOI: 10.1614/WS-D-11-00170.1.

Chinalia FA, Regali-Seleghin MH, Correa EM. 2007. 2,4-D toxicity: cause, effect and control. Terrestr Aquat Environ Toxicol 1 (2): 24-33.

Christoffoleti PJ, Figueiredo MRAD, Peres LEP, Nissen S, Gaines T. 2015. Auxinic herbicides, mechanisms of action, and weed resistance: A look into recent plant science advances. Sci Agric 72 (4): 356-362. DOI: 10.1590/0103-9016-2014-0360.

Costa LOD, Rizzardi MA. 2014. Resistance of Raphanus raphanistrum to the herbicide metsulfuron-methyl. Planta Daninha 3 (2): 181-187. DOI: $10.1590 / \mathrm{S} 0100-83582014000100020$

Crespo RJ, Wingeyer AB, Kruger GR, Riggins CW, Tranel PJ, Bernards ML. 2017. Multiple-herbicide resistance in a 2,4-D-resistant waterhemp (Amaranthus tuberculatus) population from Nebraska. Weed Sci 65 (6): 743-754. DOI: 10.1017/wsc.2017.39.

Dusenge ME, Duarte AG, Way DA. 2019. Plant carbon metabolism and climate change: elevated $\mathrm{CO} 2$ and temperature impacts on photosynthesis, photorespiration and respiration. New Phytol 221: 3249. DOI: $10.1111 / \mathrm{nph} .15283$.

Figueiredo MR, Leibhart LJ, Reicher ZJ, Tranel PJ, Nissen SJ, Westra P, Bernards ML, Kruger GR, Gaines TA, Jugalam M. 2018. Metabolism of 2,4-dichlorophenoxyacetic acid contributes to resistance in a common waterhemp (Amaranthus tuberculatus) population. Pest Manag Sci 74 (10): 2356-2362. DOI: 10.1002/ps.4811.

Ginting KA, Purba E, Ginting J. 2015. Identification of paraquat herbicide resistance in maize fields in the Tigabinanga sub-district, Karo district. Jurnal Agroteknologi 3 (2): 679-686. [Indonesian]

Guntoro D, Fitri TY. 2013. The herbicide activity of a mixture of cyhalofop-butyl and penoxulam active ingredients against several types of lowland rice weeds. Buletin Agrohorti 1 (1): 140-148. DOI: 10.29244/agrob.1.1.140-148 [Indonesian]

Hall L, Beckie H, Wolf TM. 2014. How Herbicide Work: Biology to Application. Alberta Agriculture and Rular Development, Canada.

Heap I. 2020. The International Survey of Herbicide Resistant Weeds. http://www.weedscience.com.

Hussain M, Farooq S, Merfield C, Jabran K. 2018. Mechanical Weed Control. Non-Chemical Weed Control. In: Jabran K, Chauhan BS (eds.). Non-Chemical Weed Control. Academic Press, New York. DOI: $10.1016 / \mathrm{b} 978-0-12-809881-3.00008-5$.
Indonesian Directorate of Fertilizers and Pesticides. 2016. Agricultural and Forestry Pesticides. Directorate of Agricultural Facilities and Infrastructure, Indonesia. [Indonesian]

Kurniati H. 2018. The efficacy of bispyribac sodium on the growth of weeds, crops and lowland rice yields (Oryza sativa L.). [Undergraduate Thesis]. University of Lampung, Bandar Lampung. [Indonesian]

Lu H, Yu Q, Han H, Owen MJ, Powles SB. 2019. Metribuzin resistance in a wild radish (Raphanus aphanistrum) population via both $\mathrm{psbA}$ gene mutation and enhanced metabolism. J Agric Food Chem 67 (5): 13531359. DOI: $10.1021 /$ acs.jafc.8b05974.

McCullough PE, McElroy JS, Yu J, Zhang H, Miller TB, Chen S, Johnston CR, Czarnota MA. 2016. ALS-Resistant Spotted Spurge (Chamaesyce maculata) confirmed in Georgia. Weed Sci 64 (2): 216222. DOI: $10.1614 /$ WS-D-15-00142.1.

Messinger SM, Buckley TN, Mott KA. 2006. Evidence for involvement of photosynthetic processes in the stomatal response to $\mathrm{CO} 2$. Plant Physiol 140: 771-778. DOI: 10.1104/pp.105.073676.

Nascentes RF, Carbonari CA, Simões PS, Brunelli MC, Velini ED, Duke SO. 2017. Low doses of glyphosate enhance growth, CO2 assimilation, stomatal conductance and transpiration in sugarcane and $\begin{array}{llllll}\text { eucalyptus. Pest Manag Sci } 74 & \text { (5): 1197-1205. }\end{array}$ DOI: $10.1002 / p s .4606$.

Prakoso GE. 2018. The study of resistance of several types of rice field weeds to metsulfuron-methyl and 2,4-d herbicides. [Thesis]. University of Lampung, Bandar Lampung. [Indonesian]

Rey-Caballero J, Menendez J, Bordonaba JG, Salas M, Alcantara R, Torra J. 2016. Unravelling the resistance mechanisms to 2,4-D (2,4dichlorophenoxyacetic acid) in corn poppy (Papaver rhoeas). Pestic Biochem Physiol 133: 67-72. DOI: 10.1016/j.pestbp.2016.03.002.

Rodrigues OL, Galvão JCC, Ferreira EA, Silva DV, Santos MV, Ferreira LR, Pereira RC, Felipe RS. 2014. Physiologic characteristics of corn and Urochloa brizantha (Hochst. ex A. Rich.) R.D. Webster in intercropping cultivation. Chilean J Agric Res 74 (3): 257-262. DOI: $10.4067 / \mathrm{S} 0718-58392014000300002$.

Schütte G, Eckerstorfer M, Rastelli V, Reichenbecher W, Rastrepo-Vasalli S, Ruohonen-Lehto M, Saucy AGW, Mertens M. 2017. Herbicide resistance and biodiversity: agronomic and environmental aspects of genetically modified herbicide-resistant plants. Environ Sci Europe 29 (5). DOI 10.1186/s12302-016-0100-y.

Silva DRO, Vargas L, Agostinetto D, Santos FM. 2017. Photosynthetic performance of glyphosate-resistant and glyphosate susceptible hairy fleanvane under light intensity. Planta Daninha 35: 3-8. DOI: $10.1590 / \mathrm{s} 0100-83582017350100087$.

Singh G, Singh VP. 2005. Compatibility of clodinafop-propargyl and fenoxaprop-p-ethyl against with carfentrazone-ethyl and metsulfuronmethyl and 2,4-D. Indian J Weed Sci 37: 1-5.

Singh RK, Verma SK, Prasad SK, Singh SB. 2015. Effect of metsulfuronmethyl against broadleaf weeds in wheat (Triticum aestivum $\mathrm{L}$. emend. Fiori and Paol.). J Crop Weed 11: 161-166.

Song Y. 2014. Insight into the mode of action of 2,4dichlorophenoxyacetic acid (2,4-D) as an herbicide. J Integr Plant Biol 56 (2): 106-113. DOI: 10.1111/jipb.12131.

Sureshkumar R., Reddy YA, Ravichandran S. 2016. Effect of weeds and their management in transplanted rice-a review. Impact J 4 (11): 165-180.

Tcherkez G, Limami AM. 2019. Net photosynthetic CO2 assimilation: more than just $\mathrm{CO} 2$ and $\mathrm{O} 2$ reduction cycles. New Phytol 2: 520-529. DOI: $10.1111 / \mathrm{nph} .15828$.

Tomlin CDS. 2010. A World Compendium The e-Pesticide Manual. British Crop Protection Council (BCPC), England.

Usui Y, Kasubuchi T. 2011. Effects of herbicide application on carbon dioxide, dissolved oxygen, $\mathrm{pH}$, and $\mathrm{RpH}$ in paddy-field ponded water. Soil Sci Plant Nutr 57: 1-6. DOI: 10.1080/00380768.2010.541868.

Xu Z, Zhang C, Zhang X, Liu C, Wu Z, Yang Z, Zhou K, Yang X, Li F. 2013. Transcriptome profiling reveals auxin and cytokinin regulating somatic embryogenesis in different sister lines of cotton cultivar CCRI24. J Integr Plant Biol 55: 631-642. DOI: 10.1111/jipb.12073.

Yuan X, Guo P, Qi X, Ning N, Wang H, Wang H, Wang X, Yang Y. 2013. Safety of herbicide Sigma Broad on Radix Isatidis (Isatis indigotica Fort.) seedlings and their photosynthetic physiological responses. Pestic Biochem Physiol 106: 45-50. DOI: 10.1016/j.pestbp.2013.04.002

Zhou QY, Liu WP, Zhang YS, Liu KK. 2007. Action mechanisms of acetolactate synthase-inhibiting herbicides. Pestic Biochem Physiol 89: 89-96. DOI: 10.1016/j.pestbp.2007.04.004 